\title{
ENTREVISTA A CHARLES J. FILLMORE
}

\author{
CARMEN M. BRETONES CALLEJAS \\ Universidad de Almería
}

\section{INTRODUCCIÓN: LA LINGÜÍSTICA DE FILLMORE}

Con su conocida Semántica de Marcos o "Frame Semantics" y su Gramática de Construcciones o "Construction Grammar", Fillmore saca a relucir los planteamientos teóricos fundamentales de la Lingüística Cognitiva: la idea de que el lenguaje es una parte integral de la cognición, que a su vez refleja la interacción de consideraciones culturales, psicológicas, comunicativas y funcionales. A este respecto Fillmore dice:

"The basic assumption of Frame Semantics [...] is that each word evokes a particular frame and possibly profiles some element or aspect of that frame. An "evoked" frame is the structure of knowledge required for the understanding of a given lexical or phrasal item; a "profiled" entity is the component of a frame that integrates directly into the semantic structure of the surrounding text or sentence" (Fillmore et al., 2000: 2).

La noción de marco es la base de lo que Fillmore (1985) denominara la semántica del entendimiemto o "understanding" (U-semantics), que contrasta con la que puede ser denominada semántica verdad condicionada o "truth conditional semantics" (T-semantics). Usemantics tiene como fin determinar lo que hace que un oyente obtenga una interpretación de una oración. Este es un enfoque composicional, porque sus operaciones recaen en el conocimiento de las palabras, frases y construcciones gramaticales para construir una interpretación, pero también no-composicional ya que el proceso de construcción no se guía por operaciones puramente simbólicas de abajo a arriba. En cambio, la meta de Tsemantics es determinar bajo qué condiciones una oración puede o no ser verdad, donde la verdad viene determinada composicionalmente (Fillmore, 1982: 230-232). De hecho, para él la conexión existente entre Lexical Semantics y Construction Grammar va más allá de un mero problema de representación. Construction Grammar ve la descripción de patrones gramaticales y de los propósitos semánticos y pragmáticos a los que sirven, igualmente importantes y necesarios. En Construction Grammar el marco semántico asociado con un elemento léxico proporciona alguna de la información semántica necesaria para la interpretación semántica de una oración (Fillmore, 1994). Así pues, tales relaciones léxicas no son tan interesantes como las propiedades semánticas que las palabras poseen gracias a su pertenencia a marcos. En su último libro, Language Form, Meaning and Practice (Fillmore, 2001), desarrolla cuestiones de forma del lenguaje, uso del lenguaje, y convenciones uniendo forma, significado y práctica. Por último, su mayor deseo es ver pronto un tipo de 
práctica lexicográfica que reconozca el marco base de las descripciones de sentido (ver 'FrameNet', http://www.icsi.berkeley.edu/ framenet).

\section{DATOS PERSONALES Y TRAYECTORIA PROFESIONAL}

Charles John Fillmore, para todos los que le conocen 'Chuck', nación en St. Paul, Minesota, el 9 de agosto de 1929. Hoy vive en Berkeley, California, felizmente casado con Lily Wong Fillmore. Ha sido profesor de lingüística en los cursos superiores en el departamento de lingüística de la Universidad de California en Berkeley y hoy es investigador asociado en el Instituto Internacional de la Computación (ICSI) en Berkeley, donde dirige el proyecto denominado 'FrameNet'.

Fillmore hizo Lingüística en la Universidad de Minesota en 1951, y posteriormente fue a la Universidad de Michigan donde obtuvo su M.A en 1958, y el PhD, en 1961. El título de su tesis fue $A$ System for Characterizing Phonological Theories. Entre sus méritos constan los siguientes: Profesor de distintos Intitutos como el LSA Summer Institute, Salzburg, Austria, 1979; Presidente de la Cognitive Science Society, 1980; Elección como miembro de la Academia Americana de las Artes y las Ciencias, 1984; Presidente de la Linguistic Society of America, 1991; Festschrifts: Masayoshi Shibatani y Sandra A. Thompson (eds.), dos volúmenes: Grammatical Constructions: Their Form and Meaning, Oxford 1996; Essays in Semantics and Pragmatics, Benjamins-Amsterdam 1996; y The Berkeley Citation (Uiversidad de California en Berkeley) 1998. Trabajó para la Agencia de Seguridad de la Armada de Estados Unidos de 1952 a 1955; de 1955 a 1957 fue profesor de inglés en el Kyoto Women's School, Kioto, Japón; de 1961 a 1970 fue desde Assistant Professor hasta Full Professor en la Universidad de Ohio State; en 1970-1971, fue Fellow en el Stanford Center for Advanced Study in the Behavioral Sciences; de 1971 a 1994, Professor of Linguistics en la Universidad de California en Berkeley; Director de Departamento en el Departamento de Lingüística de Berkeley, 1979-1983; Director en funciones del Institute of Cognitive Studies, 1985-1989; 1994-2001, Profesor del Programa de Doctorado de Lingüística en la Universidad de California en Berkeley. Actualmente es Research Associate en el International Computer Science Institute (ICSI), Berkeley, y director del proyecto denominado 'FrameNet'. Por último, es miembro de los siguientes tribunales editoriales: Cognitive Science, Discourse Processes, General Linguistics, Journal of Pragmatics, Journal of Psycholinguistic Research, Journal of Verbal Learning and Verbal Behavior, Linguistic Inquiry, Linguistics and Philosophy, Papers in Japanese Linguistics, International Journal of Lexicography; y de las siguientes sociedades académicas: Linguistic Society of America, Dictionary Society of North America, Association for Computational Linguistics, European Association of Lexicography, American Academy of Arts and Sciences. 


\section{ENTREVISTA PERSONAL}

Durante mi estancia en su grupo de investigación en el ICSI, Berkeley, le expresé a Fillmore mi deseo de recabar información sobre él para la realización de un ensayo sobre su persona destinado a una enciclopedia (Ecyclopedia of Linguistics, editada por Fitzroy Dearborn Publishers y publicada próximamente en Chicago). Él se brindó a darme toda la información que necesitara y a concederme una entrevista, pero al no poder encontrar un hueco para una reunión en persona por sus numerosos compromisos, el lingüista propuso dedicarme su tiempo por e-mail desde su propia casa durante el fin de semana. Agradecida e ilusionada, le envié una batería de preguntas y, gracias a la amabilidad que le caracteriza, surgió la entrevista que sigue.

\section{Sunday, September 30, 2001 5:24 PM}

CB: In order to define your trajectory, would you divide your career in phases or stages (which) or you would describe it as a continuum (of what)?

CF: This is going to be a strange encyclopedia if its interests include all of this!

Well, I started out as a phonologist, having received most of my phonological training just at the historical point where descriptive/structuralist phonology was giving way to generative phonology. I more or less knew everything that was in Kenneth Pike's textbook on Phonemics, as well as all of the papers on phonemic analysis that can be found in the Martin Joos Reader in Linguistics.

A major turning point in my thinking was a paper by Morris Halle, a review of work by a Russian linguist Avanesov. I had been writing a paper with the phonetician Gordon Peterson when the Halle influence came along the Peterson-Fillmore paper was going to be a set of principles on the basis of which it would be possible to design an automatic program for producing a phonemic analysis of any language on the basis of purely phonetic and distributional facts - and I wasn't able to influence Peterson (who was my teacher) to change the direction of the paper and was left on my own.

It was misleading to say that I started out as a phonologist: rather, that was the first (paid) work I did as a graduate student in Linguistics, at the University of Michigan. Aside from a survey paper I did with Professor Peterson and a paper with Bill Wang on "intrinsic cues for consonant perception", and a dissertation on alternative phonemic analysis of Japanese, I never did anything else in phonetics or phonology.

Actually I had studied linguistics at the University of Minnesota, in the late forties, followed by a brief period as an anthropology student, but soon after that I ended up in the U.S. Army. After one year of training in the States, I spent two years in Japan, with the Army Security Agency, where I spent eight hours a day listening to short-wave broadcasts from Soviet forces in and around Vladivostok. (I'm still probably pretty good at recognizing Russian numbers spoken against a noisy background, since almost everything I heard was in code.) In my off hours I wandered around Kyoto, trying to find out what Japan was like and to learn as much as I could about the Japanese language. 
I was discharged from the Army in Japan - I think I was the first to do that, though a couple of others did it immediately afterwards and I attended classes at Kyoto University while earning a living teaching English at a Buddhist girls school in Kyoto.

When I got back home, in 1956, I went to the University of Michigan, in Ann Arbor. At first I thought I wanted to become a Japanologist but I ended up doing the regular linguistics program.

After I got my degree I joined Bill Wang at Ohio State where he was invited to start a linguistics program there. I was associated with a funded research project, with Bill, called Project on Linguistic Analysis, and that's where I began doing lexical stuff. Bill and I taught courses in the transformationalist framework, and I became sort of evangelical about this new movement. I did some work on rule ordering (a booklet on indirect object constructions and a few related papers that nobody knows about dealt with that, and my paper on "embedding transformations", which seems to have been the first proposal for the idea of the transformational cycle, was a part of that). The interest in verbs and their complementation patterns led up to a group of papers which formulated a proposal that has been called "case grammar", and that became quickly popular. This instant popularity made me think that it had to be wrong.

I had received relief from teaching for ten weeks (one quarter) to write something on Deixis, which I somehow got interested while at Ohio State, but I spent the time writing "The case for case" instead.

I got invited to spend a year at the Center for Advanced Study in the Behavioral Sciences, in Palo Alto, for 1970-71, and failed to do any of the things I had promised to do, but I at least wrote up the "Lectures on Deixis" which got distributed in various informal ways for thirty years and finally appeared in book form last year.

While in California I got invited to move to Berkeley, and accepted.

My teaching in Berkeley at first tended to deal with rule ordering arguments in syntax, case grammar, and general linguistics. In later decades I focused on lexical semantics issues, deixis, and pragmatics, and all of that led to a strong interest in idiomaticity and fixed expressions in general, and THAT led in a sort of natural way to construction grammar. Much of this was influenced by the interdisciplinary connections fostered by the Cognitive Science program that was just getting started on the Berkeley campus. Partly through cogsci support, some interdisciplinary courses in Lexical Semantics got started (Fillmore Kay G. Lakoff) which in those days brought students from many departments.

My strongest interest in the last decade of my active teaching was construction grammar; my main interest since retirement has been in computational lexicography, through my participation in the work of the "FrameNet" project.

That's more like meandering than anything that should be dignified with the label "trajectory".

CB: - What linguist or thinkers you are influenced from and to whom have you influenced? When? How? Why? Ex. Minsky's frames, Shank's scripts, etc.

CF: My main influence while at Michigan - though it was an influence that I tried hard to reject - was the work of Kenneth Pike. It took years for me to understand that many of the 
things I believed, about meaning and grammar, resulted from interacting with Pike. Chomsky's Syntactic Structures turned me around in my attitude toward linguistics as a science, and for a brief period I considered myself a disciple of his. In the period of the ascendancy of Generative Semantics - I didn't even see it as a movement, it had become, without me really becoming aware of it, a basic way of thinking about things - I was strongly influenced by George Lakoff and Jim McCawley, just to name the two that I had most interaction with. In my work on frame semantics I wasn't so much influenced by concepts of frames, scripts, schemas, etc., in cognitive psychology and educational psychology, as I was comforted by their existence. In my thinking about construction grammar I have been influenced most by Arnold Zwicky and Paul Kay. In my lexicographic work my strongest influence has been the British lexicographer, Beryl (Sue) Atkins.

I don't know anybody that I've influenced, for good or for ill. I've had lots of bright students, but my role was mainly to get out of their way.

CB: - How does your work compare with the general development of Linguistics in the Anglo-Saxon world, -such as Chomskian theories, functionalism, and the increasingly large number of grammars that are being devised?

CF: What I liked about the generativist movement was what I took to be the desire to get all the "facts" right: one could keep polishing the grammar by introducing new principles, new rules, new lexical descriptions, new rule orderings or new rule application principles so that in the end we'd be able to account for (to "generate") all and only the grammatical sentences in the language. This attention to detail I see carried on in some of the non-transformational formal grammars that are close by, such as LFG and HPSG; I'm actually not current on what you call Chomskian theories (plural), so I can't say anything useful about that. There seem to be lots of things called "functionalism", and much of it is attractive, although I don't always know what a functionalist "explanation" is; sometimes I've heard things that sound a bit like "Language iss like this because think how awkward things would be if it weren't." But again, I don't have a large enough view to be able to say anything wise.

CB: - How do you see Lakoffs approach to Linguistics and that pervasive notion of metaphor and embodiment?

CF: I think Lakoff has established without any doubt the essential character of metaphor in the way speakers organize their ways of thinking about everyday things. I think that much of what he does is compatible with the way I think of things, in frame semantics and construction grammar, though I see myself as being more concerned than he is with getting the fussy details right.

CB: - What do you think about structuralist concerns with synonymy, antonymy and all lexical relations?

CF: If I understand the question correctly, this is something I have said something about in the "Semantics of understanding" paper. I think that lexical relations as such are not as interesting as the semantic properties that words have by virtue of their participation in frames. Do you mean by this the "structuralist" concerns with establishing word-toword relations as having significance of their own? 
CB: - Where do Lexicography and Frame Semantics come together?

$\mathrm{CF}$ : The glib answer is "FrameNet". A more careful answer is that I would like to see a kind of lexicographic practice which recognizes the "frame" background of sense descriptions. This is a complicated point which I can't develop by email.

\section{SELECCIÓN DE OBRAS DE CHARLES J. FILLMORE}

(with William S.Y. Wang, first author) "Intrinsic cues and consonant perception." 130-136. Journal of Speech and Hearing Research. 4:2(1961).

“The position of embedding transformations in a grammar." 208-231. Word 19(1963).

“The case for case.” Bach, Emmon, and Harms, Robert, editors. Universals in Linguistic Theory. Holt-Rinehart-Winston. 1-89. (Translations in German, Russian, Spanish, Portuguese, Korean, Japanese). 1968.

"Frame semantics." The Linguistic Society of Korea. Linguistics in the Morning Calm. Seoul: Hanshin. 111-137. 1982.

"Frames and the semantics of understanding." 222-254. Quaderni di Semantica 6: 2(1985).

(with Kay, Paul, and O'Connor, M. Catherine). "Regularity and idiomaticity in grammatical constructions: the case of 'let alone'." 501-538. Language 64:3 (1988).

“"Corpus linguistics' vs. 'Computer-aided armchair linguistics'." Directions in Corpus Linguistics (Proceedings from 1991 Nobel Symposium on Corpus Linguistics, Stockholm), Mouton de Gruyter. 35-60. 1992.

(with Atkins, B.T. Sue) "Starting where the dictionaries stop: the challenge for computational lexicography." Atkins, B.T.S. and Zampolli, A., editors. Computational Approach to the Lexicon. Oxford: Oxford University Press. 349393. 1994.

(with Kay, Paul, first author). "Grammatical Constructions and linguistic generalizations: the What's X doing Y? Construction”. 1-33. Language 75:1(1999).

(with Wooters, Charles, and Baker, Collin F.) "Building a Large Lexical Databank Which Provides Deep Semantics". Proceedings of the Pacific Asian Conference on Language, Information and Computation. Hong Kong. 2001.

Language Form, Meaning and Practice. Stanford: CSLI. 2001.

\section{OTRAS LECTURAS RECOMENDADAS}

Dirven, Rene, and Radden, Gunter, editors. Fillmore's case grammar : a reader. Studies in descriptive linguistics: 16. Heidelberg: J. Groos. 1987. 
Fillmore, Charles J. "The pragmatics of constructions." Dan I. Slobin, Julie Gerhardt, Amy Kyratzis, and Jiansheng Go, editors. Social Interaction, Social Context, and Language: Essays in Honor of Susan Ervin-Tripp. Mahwah, New Jersey: Lawrence Erlbaum. 1996.

Fillmore, Charles J. "A private history of the concept of case." Rene Dirven \& Gunter Radden, editors. Concepts of Case. Tubingen: Gunter Narr Verlag. 1987.

Fillmore, Charles J. Lectures on Deixis. Stanford, CA: Center for the Study of Language and Information (CSLI lecture notes; 65). 1997.

Fillmore, Charles J., et al. Construction Grammar. Stanford: CSLI. To appear.

Michaelis, Laura A., and Lambrecht, Knud. "Towards a Construction-Based Theory of Language Function: The case of nominal extraposition." 215-247. Language 72:2(1996).

Petruc, Miriam R.L. "Frame Semantics." Verschueren, Jef, and Östman, Jan-Ola, editors. Handbook of Pragmatics. Amsterdam/Philadelphia: John Benjamins. 1996. 